DOI: http://doi.org/10.21698/simi.2018.ab22

\title{
BIODIESEL FROM EDIBLE OILS: PRO AND CONS
}

\author{
Malek Msheik ${ }^{1}, \underline{\text { Diana-Luciana Cursaru }}{ }^{2}$ \\ ${ }^{1}$ Lebanese University, Hadat Campus Beirut, malek.msheik352@gmail.com, Lebanon \\ ${ }^{2}$ Petroleum-Gas University of Ploiești, b-dul București, no.39, dianapetre@upg-ploiesti.ro, \\ Romania
}

Keywords: edible oils, biodiesel, corrosion, oxidation stability

\section{Introduction}

There are already a few decades since mankind struggles to find alternative fuels to substitute petroleum, which should have the main feature of being environmentally friendly. Biodiesel is the alternative biofuel to conventional petro-diesel and there are already 25 years since biodiesel has been used as a fuel for vehicles in a pure form or as a blend in a mixture with conventional diesel fuel. Unfortunately, few drawbacks related to biodiesel synthesis and utilization, such as high susceptibility to oxidation or auto-oxidation, availability of feed stocks, food vs. fuel debate, the storage stability, hygroscopic nature, high sensitivity to light, temperature, contaminants and moisture, all of these make it so that biodiesel is not yet able to replace petro-diesel completely. Our investigations were focused mainly to examine the oxidation stability of biodiesel synthesized from different edible oils such as sunflower (SF), rapeseed (RS) and palm oil and their corrosiveness.

\section{Materials and methods}

The biodiesel used in our investigation was synthesized by catalytic transesterification of the triglycerides existing in the vegetable oils, in the presence of methanol, using $\mathrm{KOH}$ as catalyst. The transesterification was carried on in a batch reactor, keeping the reaction temperature at $60{ }^{\circ} \mathrm{C}$ and 1 atm. pressure. The main reaction product, biodiesel, was purified and characterized in order to test its oxidation stability and corrosiveness. The main physical-chemical characteristics of biodiesels are presented in Table 1.

Table 1. Physical-chemical characteristic of biodiesel

\begin{tabular}{|c|c|c|c|c|c|}
\hline \multirow[t]{2}{*}{ Characteristic } & \multirow[t]{2}{*}{ Units } & \multicolumn{3}{|c|}{ Values } & \multirow{2}{*}{$\begin{array}{l}\text { Standard } \\
\text { ASTM }\end{array}$} \\
\hline & & SF bio & RS bio & $\begin{array}{c}\text { Palm } \\
\text { bio }\end{array}$ & \\
\hline Density & $\mathrm{g} / \mathrm{cm}^{3}$ & 0.882 & 0.880 & 0.871 & D 1298 \\
\hline $\begin{array}{l}\text { Kinematic viscosity@40 } \\
{ }^{\circ} \mathrm{C}\end{array}$ & $\mathrm{mm}^{2} / \mathrm{s}$ & 4.21 & 4.41 & 4.41 & D 2270 \\
\hline Acid value & $\mathrm{mg} \mathrm{KOH} / \mathrm{g}$ & 0.36 & 0.22 & 0.42 & D 974 \\
\hline $\begin{array}{l}\text { Copper strip corrosion test } \\
\text { (a) } 50^{\circ} \mathrm{C} \text { for } 3 \mathrm{~h}\end{array}$ & - & 1 & 1 & 1 & D 130 \\
\hline Water content & $\mathrm{mg} / \mathrm{kg}$ & 50 & 44 & 37 & D 6751 \\
\hline Oxidation stability & $\mathrm{h}$ & 0.5 & 0.7 & 1.33 & D 7462 \\
\hline Pour point & ${ }^{\circ} \mathrm{C}$ & -6 & -10 & +13 & D 97 \\
\hline
\end{tabular}




\section{INTERNATIONAL SYMPOSIUM "THE ENVIRONMENT AND THE INDUSTRY", SIMI 2018, BOOK OF ABSTRACTS}

\section{Results and conclusions}

The standard for biodiesel recommends the copper strip tarnish test according to ASTM D130. The results of this test indicate only slight tarnish for biodiesel, which usually classify the biodiesel samples in $1^{\text {st }}$ corrosion class. This method indicates only marginal corrosion and cannot make a measurable difference between petrodiesel fuel, biodiesel and biodiesel blends. Therefore, other unstandardized test has been used regarding the corrosiveness tendency of biodiesel particularly with copper. These tests consists of immersing the copper plate into the biodiesel sample under 60 ${ }^{\circ} \mathrm{C}$ and remove it after 500 hours and after 1000 hours to see how much the plate losses weight. The corrosion rate was calculated with equation 1.

$$
\text { Corrosion rate }(m p y)=\frac{534 \times \Delta w}{D \times t \times A}
$$

where: mpy is mils per year ( 1 mils is $0.001 \mathrm{in}), \Delta \mathrm{w}$ is the weight loss (mg), D is the density of copper $\left(\mathrm{g} / \mathrm{cm}^{3}\right)$ and it is $8.96, \mathrm{t}$ is the exposure time in hours (h), $\mathrm{A}$ is the exposed surface area $\left(\mathrm{in}^{2}\right)$.

The standard specifications allowed maximum corrosiveness of one mpy and the results for biodiesels are shown in the Table 2.

Table 2. Corrosion rates of biodiesels

\begin{tabular}{clcccc}
\hline & & \multicolumn{4}{c}{ Corrosion rates, mpy } \\
\cline { 2 - 6 } & & SF bio & RS bio & Palm bio & Diesel \\
\hline Exposure & 500 & 1.45 & 0.97 & 0.76 & 0.25 \\
\cline { 2 - 6 } time, $\mathrm{h}$ & 1000 & 1.78 & 1.20 & 0.97 & 0.32 \\
\hline
\end{tabular}

The palm biodiesel corroding behaviour is still in the allowed range, even it is more corrosive than conventional petro-diesel, but rapeseed biodiesel and sunflower biodiesel exceed the maximum value allowed.

The oxidation stability of biodiesel was determined by the Rancimat method according to ASTM D 7462 standard. The results are depicted in Table 1. According to the oxidation investigations, none of the biodiesels did not fulfill the minimum limit of 6 hours imposed by standard for biodiesel, therefore different concentrations of an antioxidant additive (phenylhydrazine) were used in order to improve the oxidation stability of palm biodiesel. The results are presented in Table 3.

Table 3. Induction time (IP) for palm biodiesel after additivation

\begin{tabular}{lcccccc}
\hline \multicolumn{7}{c}{ Palm biodiesel + additive $(\mathrm{ppm})$} \\
\hline Additive & 0 & 500 & 1000 & 1500 & 2000 & 2500 \\
\hline $\mathrm{IP}, \mathrm{h}$ & 1.33 & 3.09 & 3.37 & 5.12 & 5.5 & 6.1 \\
\hline
\end{tabular}

